\title{
Activation of Coagulation and Fibrinolysis During Coronary Artery Bypass Grafting: A Comparison Between On-Pump and Off-Pump Techniques
}

\author{
Shreosee Roy $\cdot$ Kaushik Saha $\cdot$ Krishnendu Mukherjee • \\ Santanu Dutta • Debasis Mukhopadhyay • \\ Indranil Das · Gargi Raychaudhuri
}

Received: 16 December 2012/ Accepted: 13 March 2013/Published online: 26 April 2013

(C) Indian Society of Haematology \& Transfusion Medicine 2013

\begin{abstract}
Coronary artery bypass grafting (CABG) with cardiopulmonary bypass (CPB) is associated with intense activation of hemostatic mechanisms. But the precise knowledge of the effects of eliminating CPB in patients undergoing off-pump coronary artery bypass grafting (CABG) are not well established. The present study was carried out to compare and document the changes in selected coagulation and fibrinolysis variables in patients undergoing on-pump and off-pump CABG (OPCAB). A total of 42 patients of on-pump and 31 patients of off-pump CABG were selected for the study. Platelet count, prothrombin time (PT), activated partial thromboplastin time (APTT), thrombin time
\end{abstract}

S. Roy $\cdot$ K. Saha $(\bowtie) \cdot$ D. Mukhopadhyay $\cdot$ I. Das

Department of Pathology, IPGME \& R, Kolkata, India

e-mail: drkaushik.saha@yahoo.com

S. Roy

e-mail: shreoseeroy@yahoo.in

Present Address:

S. Roy

Ganganiketan, Jamtala, Kalna Road, Burdwan 713101, India

Present Address:

K. Saha

42/9/2, Sashi Bhusan Neogi Garden Lane, Baranagar, Kolkata 700 036, India

K. Mukherjee

Department of Immunohematology and Transfusion Medicine, Medical College, Kolkata, India

S. Dutta

Department of Cardiothoracic Surgery, IPGME \& R, Kolkata, India

G. Raychaudhuri

Department of Pathology, College of Medicine and Sagore Dutta Hospital, Kolkata, India
(TT), Fibrinogen and D-dimer levels were measured immediately, $24 \mathrm{~h}$ and 7 days after operation and compared with the baseline preoperative values. Statistical analysis was done by mixed ANOVA for repeated measures and Posthoc tests using the Bonferroni correction, Chi square and unpaired $t$ test. All the parameters were significantly changed $(P<0.05)$ with the time. Platelet counts, fibrinogen and D-dimer levels were significantly different between onpump and off-pump CABG patients on immediate and $24 \mathrm{~h}$ postoperative period and attained almost same level after 7 days of operation. Fibrinogen level and platelet counts were increased after a sharp fall in the immediate postoperative period whereas D-dimer levels were persistently increased with a sharp peak of rise in the immediate postoperative period in on-pump group. On-pump surgery was associated with excessive fibrinolytic activity immediately after operation. The off-pump group demonstrated less activation of coagulation and fibrinolysis and delayed postoperative response that became almost equal to the on-pump group in the later postoperative period.

Keywords Coronary artery bypass grafting (CABG) . On-pump · Off-pump · Fibrinolysis · Coagulation ·

Hemostasis - Cardiopulmonary bypass (CPB) .

Off-pump CABG (OPCAB)

\section{Introduction}

Off-pump coronary artery bypass grafting (OPCAB) has been established as an alternative to on-pump coronary artery bypass grafting with cardiopulmonary bypass $(\mathrm{CPB})$. OPCAB can be performed on all coronary artery systems with good early [1] and midterm [2] results. The potential advantages of OPCAB are still issues of debate; however, 
the whole body inflammatory reaction caused by CPB may be attenuated. Studies, mainly performed in patients undergoing coronary artery bypass grafting $(\mathrm{CABG})$, have shown that $\mathrm{CPB}$ use is associated with activation of several metabolic pathways and cellular components leading to a systemic inflammatory response [3]. This response has mainly been documented to occur in the early hours after surgery, but some studies have shown a marked activation of the hemostatic, thrombotic, and inflammatory systems to persist for several weeks after coronary surgery [4-7]. The clinical advantage of OPCAB versus standard on-pump CABG is, however, still debated $[8,9]$. It is also unclear whether $\mathrm{CPB}$ is the main cause of the postoperative inflammatory and procoagulant responses that occur after cardiac surgery; recently, it has been hypothesized that surgical trauma, in addition to CPB, may cause activation of inflammatory and coagulation-fibrinolytic pathways [10]. Despite efforts to improve the biocompatibility of the circuits for extracorporeal circulation, activation of inflammatory pathways of coagulation and fibrinolysis remains of major concern for the potential pathologic consequences. We therefore investigated whether activation of coagulation and fibrinolysis differed between patients undergoing on-pump and off-pump CABG at the end of surgery.

\section{Materials and Methods}

\section{Study Design}

The present study was conducted in 73 consecutive patients, who came to the department of Cardiothoracic Surgery in one and half year (01.01.2011-30.06.2012) of the study period requiring elective CABG according to guidelines [11] for surgical revascularization established by the American College of Cardiology (ACC) and American Heart Association (AHA), considered suitable for both on-pump and OPCAB procedures, were enrolled in the study. Patients were assigned to undergo on-pump $(n=42)$ or off-pump $(n=31)$ surgery depending on simple random allocation method. The study was carried out after obtaining the proper approval from the ethical committee of the institution and after getting the informed consent from patient party.

\section{Inclusion Criteria}

1. Patients with ejection fraction $>35 \%$

2. Willingness to undergo myocardial revascularization with either method (CPB or OPCAB).
Exclusion Criteria

1. Age $>80$ years

2. Ejection fraction $\leq 35 \%$

3. Serum creatinine $>150 \mu \mathrm{mol} / \mathrm{L}$

4. Tight main stem stenosis

5. Redo operation

6. Diffuse distal coronary artery disease

7. Unstable angina and Class 4 angina

8. History of cerebrovascular disease

9. Renal or liver dysfunction

10. Intake of drugs affecting platelet function, coagulation or fibrinolysis within 10 days before surgery or known pre-existing hemolytic or coagulative disorders

11. Excessive $(>1,000 \mathrm{~mL} /$ day $)$ postoperative bleeding or re exploration for bleeding, perioperative myocardial infarction

12. Emergency surgery, concomitant major surgery, unstable angina requiring emergency revascularization, valvular disease, left ventricular aneurysm requiring repair, heart failure.

Surgery and Anesthesia

The patients underwent a standard median sternotomy operation. Similar standardized anesthetic protocol was used in both types of surgery. On-pump surgery was performed with CPB in combination with cold crystalloid cardioplegia for myocardial protection. Off-pump surgery was performed on the beating, normothermic heart with local cardiac wall immobilization with an Octopus tissue stabilizer. During onpump surgery, patients were cooled to $32{ }^{\circ} \mathrm{C}$, whereas during off-pump surgery, patients were actively warmed to maintain a core temperature not lower than $35^{\circ} \mathrm{C}$. Before connection to $\mathrm{CPB}$ in on-pump group, heparin was administered at a dose of $300 \mathrm{IU} / \mathrm{kg}$ to achieve an activated coagulation time (ACT) of more than $450 \mathrm{~s}$. At the end of CPB, heparin was neutralized by protamine chloride at a dose of $3 \mathrm{mg} / \mathrm{kg}$ and additional protamine was administered until the ACT was less than $150 \mathrm{~s}$. Before the anastomosis was started, heparin at a dose of $150 \mathrm{IU} / \mathrm{kg}$ was administered to achieve an ACT of more than $250 \mathrm{~s}$ in off-pump (OPCAB) group. At the end of the operation, protamine $(25-50 \mathrm{mg})$ was administered if an $\mathrm{ACT}>150 \mathrm{~s}$ was measured. All patients were admitted postoperatively in the intensive care unit and extubated when hemodynamically stable, fully rewarmed, awake, without surgical bleeding, and with optimal blood gases.

\section{Blood Sampling}

Venous blood samples were drawn at the following intervals: preoperatively after the induction of anesthesia (Time 
1), immediately after completion of surgery (Time 2), $24 \mathrm{~h}$ (Time 3) and 7 days (Time 4) later. Plasma samples were obtained within $1 \mathrm{~h}$ after venipuncture from blood anticoagulated with trisodium citrate after centrifugation for $20 \mathrm{~min}$ at $2,000 \times \mathrm{g}$ and frozen at $-80{ }^{\circ} \mathrm{C}$ until assayed.

\section{Assay Methods}

Hematocrit, hemoglobin, and platelet counts were measured with an automated hematology analyzer (KX-21, Sysmex Corporation, Japan). Platelet counts were crosschecked with well-prepared peripheral blood films. Prothrombin time (PT), activated partial thromboplastin time (APTT), thrombin time (TT) and fibrinogen level were analyzed by automated blood coagulation analyzer (CA-50, Sysmex Corporation, Japan) using Thromborel S (Siemens, Germany), Dade Actin FSL (Siemens, Germany), Test Thrombin (Siemens, Germany) and Dade fibrinogen determination reagents (Dade Behring, Germany) respectively. D-dimer levels were assessed quantitatively by immunoturbidimetric method (STA-Liatest, Diagnostica
Stago). The analysis was conducted for both unadjusted data and for data adjusted for dilution depending on hematocrit value using the following formula: corrected parameter $=($ measured parameter $\times$ initial hematocrit $) /$ measured hematocrit.

Statistical Methods

Statistical analysis was done by mixed ANOVA for repeated measures with a Greenhouse-Geisser correction and Post-hoc tests using the Bonferroni correction, Chi square and unpaired $t$ test using IBM SPSS statistics version 20 and MedCalc software. $P$ value $<0.05$ was considered statistically significant.

\section{Results}

Patient characteristics are listed in Table 1. Demographic and perioperative variables were similar in both groups,
Table 1 Perioperative clinical variables in the study population

$s$ significant, NS non-significant, $t$ unpaired $t$ test, CS Chi Square test, $S$ single vessel disease, $D$ double vessel disease, $T$ triple vessel disease, $L M$ left main stenosis

${ }^{\text {a }}$ Body surface area calculated according to Mosteller's formula

b Severity of angina was graded according to Canadian Cardiovascular Society (CCS)

\begin{tabular}{|c|c|c|c|c|}
\hline Variable & $\begin{array}{l}\text { CPB group } \\
(n=42)\end{array}$ & $\begin{array}{l}\text { OPCAB group } \\
(n=31)\end{array}$ & $P$ value & $\begin{array}{l}\text { Test (Chi } \\
\text { square/t test) }\end{array}$ \\
\hline Age (Year) & $60.21 \pm 6.88$ & $61.74 \pm 7.29$ & $0.364, \mathrm{NS}$ & $\mathrm{t}$ \\
\hline $\operatorname{Sex}(M / F)$ & $29 / 13$ & $24 / 7$ & $0.428, \mathrm{NS}$ & $\mathrm{CS}$ \\
\hline Weight (Kg) & $75.95 \pm 9.80$ & $74.52 \pm 10.0$ & $0.541, \mathrm{NS}$ & $\mathrm{t}$ \\
\hline Body surface area $\left(\mathrm{m}^{2}\right)^{\mathrm{a}}$ & $1.863 \pm 0.15$ & $1.857 \pm 0.15$ & $0.874, \mathrm{NS}$ & $\mathrm{t}$ \\
\hline BMI $\left(\mathrm{Kg} / \mathrm{m}^{2}\right)$ & $27.75 \pm 2.67$ & $26.49 \pm 3.48$ & $0.085, \mathrm{NS}$ & $\mathrm{t}$ \\
\hline MI & $23(54.8 \%)$ & $19(61.3 \%)$ & $0.577, \mathrm{NS}$ & $\mathrm{CS}$ \\
\hline $\mathrm{DM}$ & $14(33.3 \%)$ & $13(41.9 \%)$ & $0.452, \mathrm{NS}$ & $\mathrm{CS}$ \\
\hline Hypertension & $25(59.5 \%)$ & $20(64.5 \%)$ & $0.665, \mathrm{NS}$ & $\mathrm{CS}$ \\
\hline Smoker & $16(38.1 \%)$ & $14(45.2 \%)$ & $0.544, \mathrm{NS}$ & $\mathrm{CS}$ \\
\hline COPD & $11(26.2 \%)$ & $11(35.5 \%)$ & $0.392, \mathrm{NS}$ & $\mathrm{CS}$ \\
\hline Hyperlipidemia & $32(76.2 \%)$ & $25(80.6 \%)$ & $0.649, \mathrm{NS}$ & $\mathrm{CS}$ \\
\hline Angina class $(\leq 2 \& 3)^{\mathrm{b}}$ & $31 \& 11$ & $22 \& 9$ & $0.788, \mathrm{NS}$ & CS \\
\hline Type of vessel Involved (S,D,T,LM) & $4,13,24,1$ & $3,7,20,1$ & $0.882, \mathrm{NS}$ & $\mathrm{CS}$ \\
\hline Ejection fraction $(\%)$ & $53.79 \pm 6.04$ & $56.45 \pm 5.50$ & $0.057, \mathrm{NS}$ & $\mathrm{t}$ \\
\hline Creatinine $(\mu \mathrm{mol} / \mathrm{L})$ & $93.38 \pm 6.94$ & $93.48 \pm 6.32$ & $0.948, \mathrm{NS}$ & $\mathrm{t}$ \\
\hline Blood transfusion & $12(28.6 \%)$ & $7(22.6 \%)$ & $0.564, \mathrm{NS}$ & $\mathrm{CS}$ \\
\hline No. of units tranfused & $0.69 \pm 1.18$ & $0.55 \pm 1.12$ & $0.605, \mathrm{NS}$ & $\mathrm{t}$ \\
\hline Bleeding during surgery $(\mathrm{mL})$ & $591.31 \pm 90.52$ & $632.13 \pm 115.19$ & $0.108, \mathrm{NS}$ & $\mathrm{t}$ \\
\hline Post-operative bleeding (mL) & $546.67 \pm 65.08$ & $566.90 \pm 93.41$ & $0.306, \mathrm{NS}$ & $\mathrm{t}$ \\
\hline Duration of surgery (min) & $298.07 \pm 26.64$ & $347.94 \pm 44.26$ & $0.000, \mathrm{~s}$ & $\mathrm{t}$ \\
\hline Heparin (1,000 IU) & $22.904 \pm 2.95$ & $11.213 \pm 1.5$ & $0.000, \mathrm{~s}$ & $\mathrm{t}$ \\
\hline Protamine (mg) & $257.05 \pm 33.79$ & $18.45 \pm 20.44$ & $0.000, \mathrm{~s}$ & $\mathrm{t}$ \\
\hline Antifibrinolytic therapy & $9(21.4 \%)$ & $4(12.9 \%)$ & $0.347, \mathrm{NS}$ & $\mathrm{CS}$ \\
\hline ICCU stay (days) & $2.52 \pm 0.80$ & $2.77 \pm 0.99$ & 0.470, NS & $\mathrm{CS}$ \\
\hline Hospital stay (days) & $9.64 \pm 1.59$ & $10.10 \pm 1.85$ & $0.328, \mathrm{NS}$ & $\mathrm{CS}$ \\
\hline
\end{tabular}




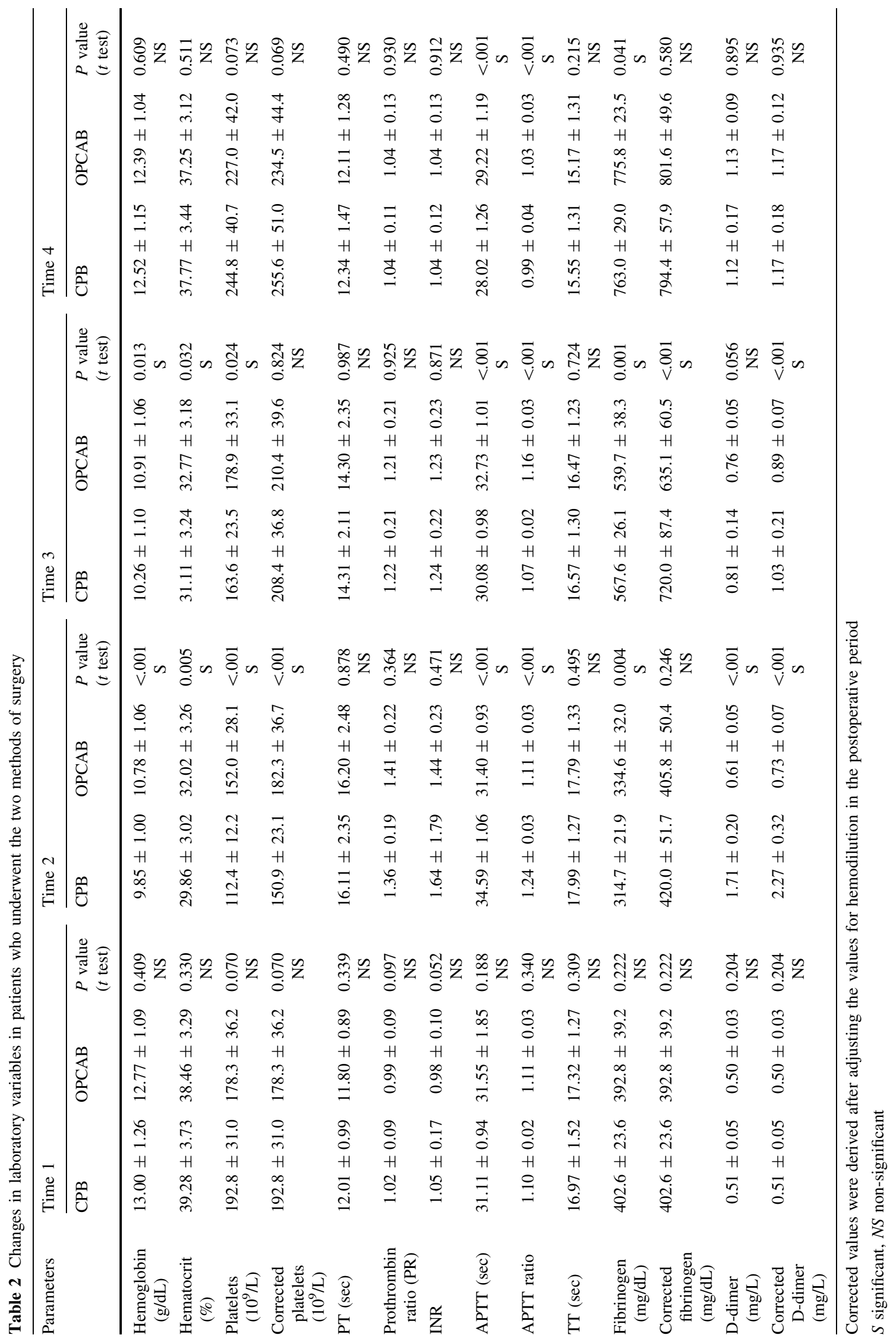


except for the use of heparin and protamine and duration of surgery. Values of all the variables of two groups of patients at four time points are summarized in the Table 2 where most of the variables are showing significant differences $(P$ value $<0.05)$ between two groups of patients on 2nd and 3rd time points except PT, PR, INR and TT. Repeated measures ANOVA with a Greenhouse-Geisser correction (Table 3) revealed an overall significant difference over time for all the parameters, time-group interactions were significant in all the parameters except PT, PR and INR, overall group differences were significant only in adjusted fibrinogen level, unadjusted and adjusted D-dimer levels. Most of the parameters demonstrated significant differences $(P$ value $<0.05)$ on pair-wise comparison of laboratory variables between two time-points by Bonferroni's Post-hoc test (Table 4). Changes in hemoglobin level with time are clearly depicted in Fig. 1 in two groups of patients. Platelet counts, fibrinogen and D-dimer levels were significantly different between on-pump and offpump CABG patients on immediate and $24 \mathrm{~h}$ postoperative

Table 3 Changes in laboratory variables in respect to time, group (on-pump and off-pump) and time-group interaction as analyzed by repeated measures ANOVA with Greenhouse-Geisser correction

\begin{tabular}{|c|c|c|c|}
\hline Parameters & $\begin{array}{l}P \text { value of } \\
\text { within subject } \\
\text { effect (i.e. time } \\
\text { effect) }\end{array}$ & $\begin{array}{l}\text { P value of } \\
\text { time-group } \\
\text { interaction } \\
\text { effect }\end{array}$ & $\begin{array}{l}\text { P value of } \\
\text { between subject } \\
\text { effect (i.e. group } \\
\text { effect) }\end{array}$ \\
\hline $\begin{array}{l}\text { Hemoglobin } \\
(\mathrm{g} / \mathrm{dL})\end{array}$ & $<0.001, \mathrm{~S}$ & $<0.001, \mathrm{~S}$ & $0.186, \mathrm{NS}$ \\
\hline $\begin{array}{l}\text { Hematocrit } \\
(\%)\end{array}$ & $<0.001, \mathrm{~S}$ & $<0.001, \mathrm{~S}$ & $0.359, \mathrm{NS}$ \\
\hline $\begin{array}{l}\text { Platelets } \\
\left(10^{9} / \mathrm{L}\right)\end{array}$ & $<0.001, \mathrm{~S}$ & $<0.001, \mathrm{~S}$ & $0.278, \mathrm{NS}$ \\
\hline $\begin{array}{c}\text { Corrected } \\
\text { platelets } \\
\left(10^{9} / \mathrm{L}\right)\end{array}$ & $<0.001, \mathrm{~S}$ & $<0.001, \mathrm{~S}$ & $0.928, \mathrm{NS}$ \\
\hline PT (sec) & $<0.001, \mathrm{~S}$ & $0.804, \mathrm{NS}$ & $0.777, \mathrm{NS}$ \\
\hline $\begin{array}{l}\text { Prothrombin } \\
\text { ratio }(\mathrm{PR})\end{array}$ & $<0.001, \mathrm{~S}$ & $0.371, \mathrm{NS}$ & $0.997, \mathrm{NS}$ \\
\hline INR & $0.004, \mathrm{~S}$ & $0.592, \mathrm{NS}$ & $0.402, \mathrm{NS}$ \\
\hline APTT (sec) & $<0.001, \mathrm{~S}$ & $<0.001, \mathrm{~S}$ & $0.091, \mathrm{NS}$ \\
\hline APTT ratio & $<0.001, \mathrm{~S}$ & $<0.001, \mathrm{~S}$ & $0.654, \mathrm{NS}$ \\
\hline TT (sec) & $<0.001, \mathrm{~S}$ & $<0.001, \mathrm{~S}$ & $0.768, \mathrm{NS}$ \\
\hline $\begin{array}{l}\text { Fibrinogen } \\
\text { (mg/dL) }\end{array}$ & $<0.001, \mathrm{~S}$ & $<0.001, \mathrm{~S}$ & $0.158, \mathrm{NS}$ \\
\hline $\begin{array}{l}\text { Corrected } \\
\text { fibrinogen } \\
(\mathrm{mg} / \mathrm{dL})\end{array}$ & $<0.001, \mathrm{~S}$ & $<0.001, \mathrm{~S}$ & $0.001, \mathrm{~S}$ \\
\hline $\begin{array}{l}\text { D-dimer } \\
(\mathrm{mg} / \mathrm{L})\end{array}$ & $<0.001, \mathrm{~S}$ & $<0.001, \mathrm{~S}$ & $<0.001, \mathrm{~S}$ \\
\hline $\begin{array}{l}\text { Corrected } \\
\text { D-dimer } \\
(\mathrm{mg} / \mathrm{L})\end{array}$ & $<0.001, \mathrm{~S}$ & $<0.001, \mathrm{~S}$ & $<0.001, \mathrm{~S}$ \\
\hline
\end{tabular}

$S$ significant, $N S$ non-significant period and attained almost same level after 7 days of operation. Platelet counts and fibrinogen levels were increased after a sharp fall in the immediate post-operative period (Figs. 2a, b, 3a, b) whereas D-dimer levels (Fig. 4a, b) were persistently increased with a sharp peak of rise in the immediate post-operative period in on-pump group.

\section{Discussion}

The abnormalities of coagulation and fibrinolysis variables associated with CPB heart surgery have been extensively investigated because of the occurrence of hemorrhagic perioperative syndromes, which significantly complicates the outcome of heart surgery patients [12]. Recently, OP$\mathrm{CAB}$ has been revisited because of the introduction of stabilizer systems permitting satisfactory results, [13, 14] and an increasing number of centers have adopted this modality of surgery as their first choice [15-18]. Because of the obvious difference in the degree of hemodilution occurring with the two surgical modalities, we chose to adjust the changes in hemostatic variables for those observed in hematocrit values. Our results show that after correction for the variables, differences in platelet counts between two groups were reduced, sharp fall in fibrinogen level in immediate postoperative period was corrected to a greater extent and the sharp peak of rise of D-dimer level in the immediate post-operative period more increased in onpump group. This prospective study demonstrated a tendency towards decreased activation of both coagulation and fibrinolysis in low risk patients during elective $\mathrm{OPCAB}$ compared with $\mathrm{CPB}$. To exactly evaluate the role of $\mathrm{CPB}$ the same level of heparinization would have been needed.

Casati et al. [19] reported consumption of antithrombin and fibrinogen in both groups but plasminogen activation and D-dimer formation during surgery in the CPB group only. Englberger et al. [20] found reduced activation of both coagulation and fibrinolysis in OPCAB patients. Several investigators [21-23] have previously demonstrated increased levels of $\mathrm{F} 1+2$ in patients undergoing cardiac operations with CPB. Casati et al. [19] reported a decrease in platelet count during surgery and an increase $24 \mathrm{~h}$ after surgery in the CPB and no important changes in the OPCAB group. Møller and Steinbrüchel [24] demonstrated an increase in platelet activation after OPCAB and a temporary platelet dysfunction in the $\mathrm{CPB}$ group. A limitation of our study was that we did not measure the platelet functions.

The incidences of thrombotic events such as stroke and myocardial infarction were similar in the on-pump and offpump groups. The technique of coronary bypass surgery 
Table 4 Comparison of laboratory variables between two time-points by Bonferroni's Post-hoc test

\begin{tabular}{|c|c|c|c|c|c|c|}
\hline \multirow[b]{2}{*}{ Parameters } & \multicolumn{6}{|c|}{$P$ values of pairwise comparisons between time points $(1,2,3,4)(n=73)$} \\
\hline & T1 vs. T2 & T1 vs. T3 & T1 vs. T4 & $\mathrm{T} 2$ vs. T3 & $\mathrm{T} 2$ vs. T4 & T3 vs. T4 \\
\hline Hemoglobin $(\mathrm{g} / \mathrm{dL})$ & $<0.001, \mathrm{~S}$ & $<0.001, \mathrm{~S}$ & $<0.001, \mathrm{~S}$ & $<0.001, \mathrm{~S}$ & $<0.001, \mathrm{~S}$ & $<0.001, \mathrm{~S}$ \\
\hline Hematocrit $(\%)$ & $<0.001, \mathrm{~S}$ & $<0.001, \mathrm{~S}$ & $<0.001, \mathrm{~S}$ & $<0.001, \mathrm{~S}$ & $<0.001, \mathrm{~S}$ & $<0.001, \mathrm{~S}$ \\
\hline Platelets $\left(10^{9} / \mathrm{L}\right)$ & $<0.001, \mathrm{~S}$ & $0.016, \mathrm{~S}$ & $<0.001, \mathrm{~S}$ & $<0.001, \mathrm{~S}$ & $<0.001, \mathrm{~S}$ & $<0.001, \mathrm{~S}$ \\
\hline Corrected platelets $\left(10^{9} / \mathrm{L}\right)$ & $<0.001, \mathrm{~S}$ & $<0.001, \mathrm{~S}$ & $<0.001, \mathrm{~S}$ & $<0.001, \mathrm{~S}$ & $<0.001, \mathrm{~S}$ & $<0.001, \mathrm{~S}$ \\
\hline PT (sec) & $<0.001, \mathrm{~S}$ & $<0.001, \mathrm{~S}$ & $0.631, \mathrm{NS}$ & $<0.001, \mathrm{~S}$ & $<0.001, \mathrm{~S}$ & $<0.001, \mathrm{~S}$ \\
\hline Prothrombin ratio (PR) & $<0.001, \mathrm{~S}$ & $<0.001, \mathrm{~S}$ & $0.493, \mathrm{NS}$ & $<0.001, \mathrm{~S}$ & $<0.001, \mathrm{~S}$ & $<0.001, \mathrm{~S}$ \\
\hline INR & $0.012, \mathrm{~S}$ & $<0.001, \mathrm{~S}$ & $1.000, \mathrm{NS}$ & $0.377, \mathrm{NS}$ & $0.017, \mathrm{~S}$ & $<0.001, \mathrm{~S}$ \\
\hline APTT (sec) & $<0.001, \mathrm{~S}$ & $1.000, \mathrm{NS}$ & $<0.001, \mathrm{~S}$ & $<0.001, \mathrm{~S}$ & $<0.001, \mathrm{~S}$ & $<0.001, \mathrm{~S}$ \\
\hline APTT ratio & $<0.001, \mathrm{~S}$ & $0.001, \mathrm{~S}$ & $<0.001, \mathrm{~S}$ & $<0.001, \mathrm{~S}$ & $<0.001, \mathrm{~S}$ & $<0.001, \mathrm{~S}$ \\
\hline $\mathrm{TT}(\mathrm{sec})$ & $<0.001, \mathrm{~S}$ & $<0.001, \mathrm{~S}$ & $<0.001, \mathrm{~S}$ & $<0.001, \mathrm{~S}$ & $<0.001, \mathrm{~S}$ & $<0.001, \mathrm{~S}$ \\
\hline Fibrinogen $(\mathrm{mg} / \mathrm{dL})$ & $<0.001, \mathrm{~S}$ & $<0.001, \mathrm{~S}$ & $<0.001, \mathrm{~S}$ & $<0.001, \mathrm{~S}$ & $<0.001, \mathrm{~S}$ & $<0.001, \mathrm{~S}$ \\
\hline Corrected fibrinogen $(\mathrm{mg} / \mathrm{dL})$ & $0.135, \mathrm{NS}$ & $<0.001, \mathrm{~S}$ & $<0.001, \mathrm{~S}$ & $<0.001, \mathrm{~S}$ & $<0.001, \mathrm{~S}$ & $<0.001, \mathrm{~S}$ \\
\hline D-dimer $(\mathrm{mg} / \mathrm{L})$ & $<0.001, \mathrm{~S}$ & $<0.001, \mathrm{~S}$ & $<0.001, \mathrm{~S}$ & $<0.001, \mathrm{~S}$ & $0.434, \mathrm{NS}$ & $<0.001, \mathrm{~S}$ \\
\hline Corrected D-dimer (mg/L) & $<0.001, \mathrm{~S}$ & $<0.001, \mathrm{~S}$ & $<0.001, \mathrm{~S}$ & $<0.001, \mathrm{~S}$ & $<0.001, \mathrm{~S}$ & $<0.001, \mathrm{~S}$ \\
\hline
\end{tabular}

$S$ significant, $N S$ non-significant

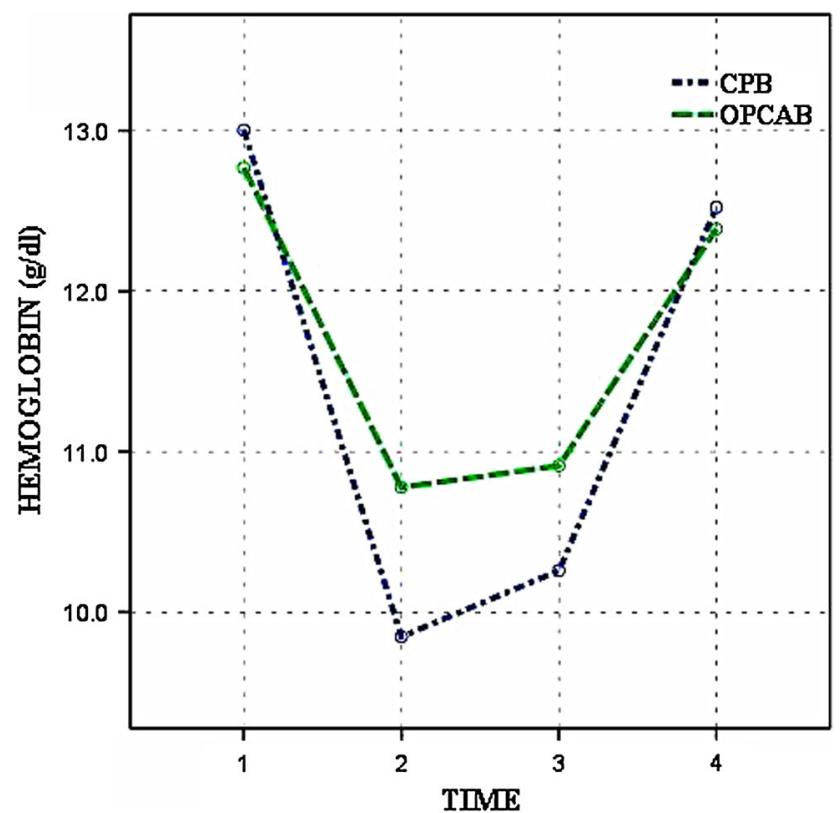

Fig. 1 Hemoglobin level at four time points in two groups of patients. Data points represent mean

was not identified as independent predictors of long-term (10 years) mortality [25].

Other studies have consequently compared the activation of the coagulation system in patients undergoing CABG with or without CPB. Englberger et al. [20] analyzed 27 patients assigned in a randomized fashion to undergo myocardial revascularization either with the offpump technique (9 patients) or with CPB (16 patients). Plasma levels of fibrin monomer, thrombin-antithrombin complex and D-dimer were significantly higher in the on-
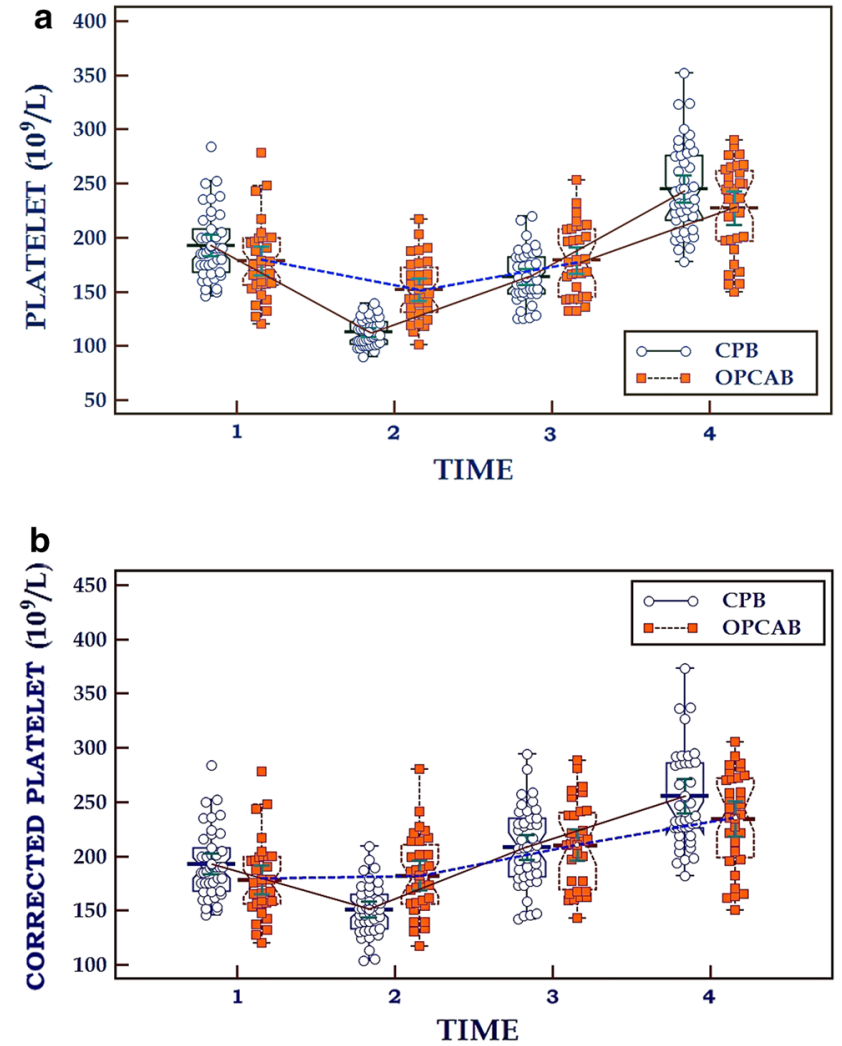

Fig. 2 a Platelet count at four time points in two groups of patients without correction for hemodilution. Data points represent mean. b Platelet count at four time points in two groups of patients after correction for hemodilution. Data points represent mean

pump group immediately after surgery, whereas they were similar $18 \mathrm{~h}$ postoperatively. Lo et al. [26] evaluated 40 patients who underwent coronary surgery with or without 

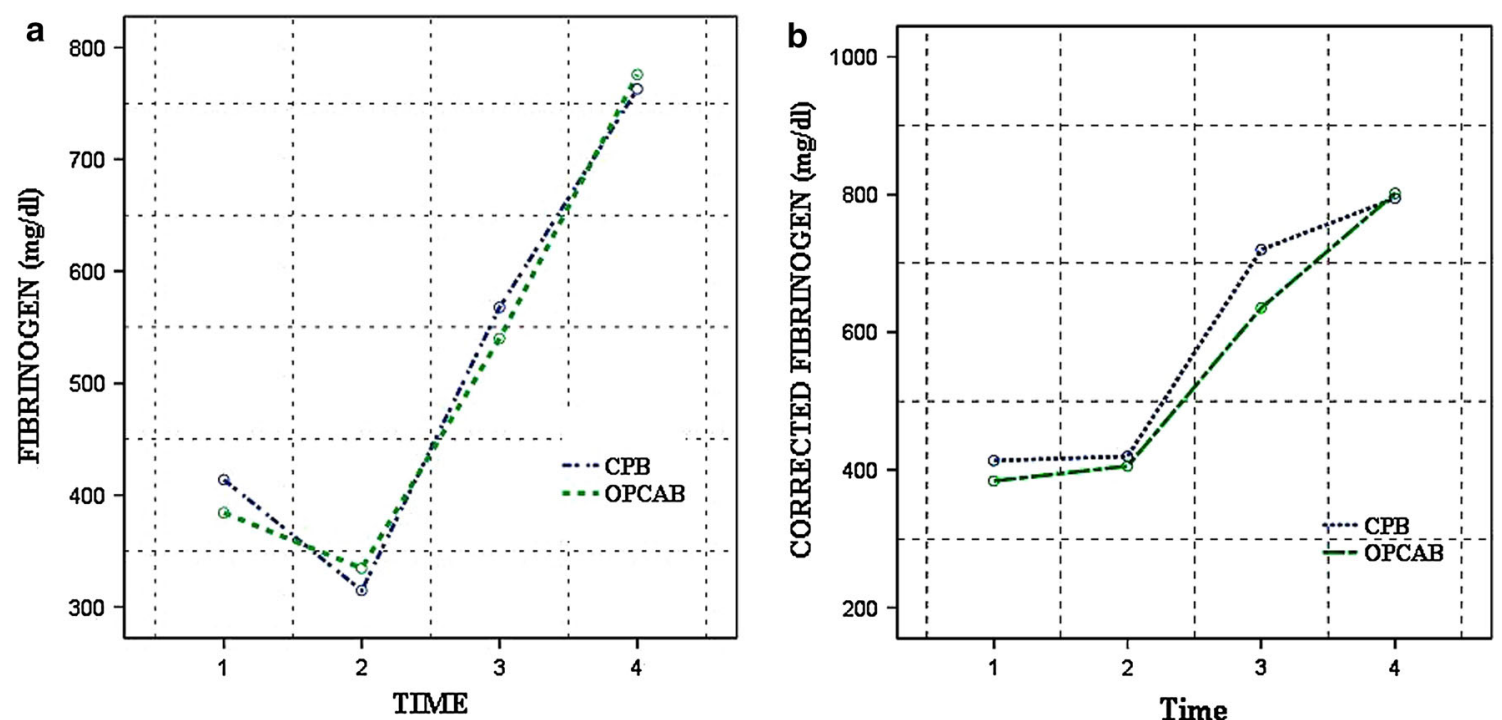

Fig. 3 a Fibrinogen level at four time points in two groups of patients without correction for hemodilution. Data points represent mean. b Fibrinogen level at four time points in two groups of patients with correction for hemodilution. Data points represent mean
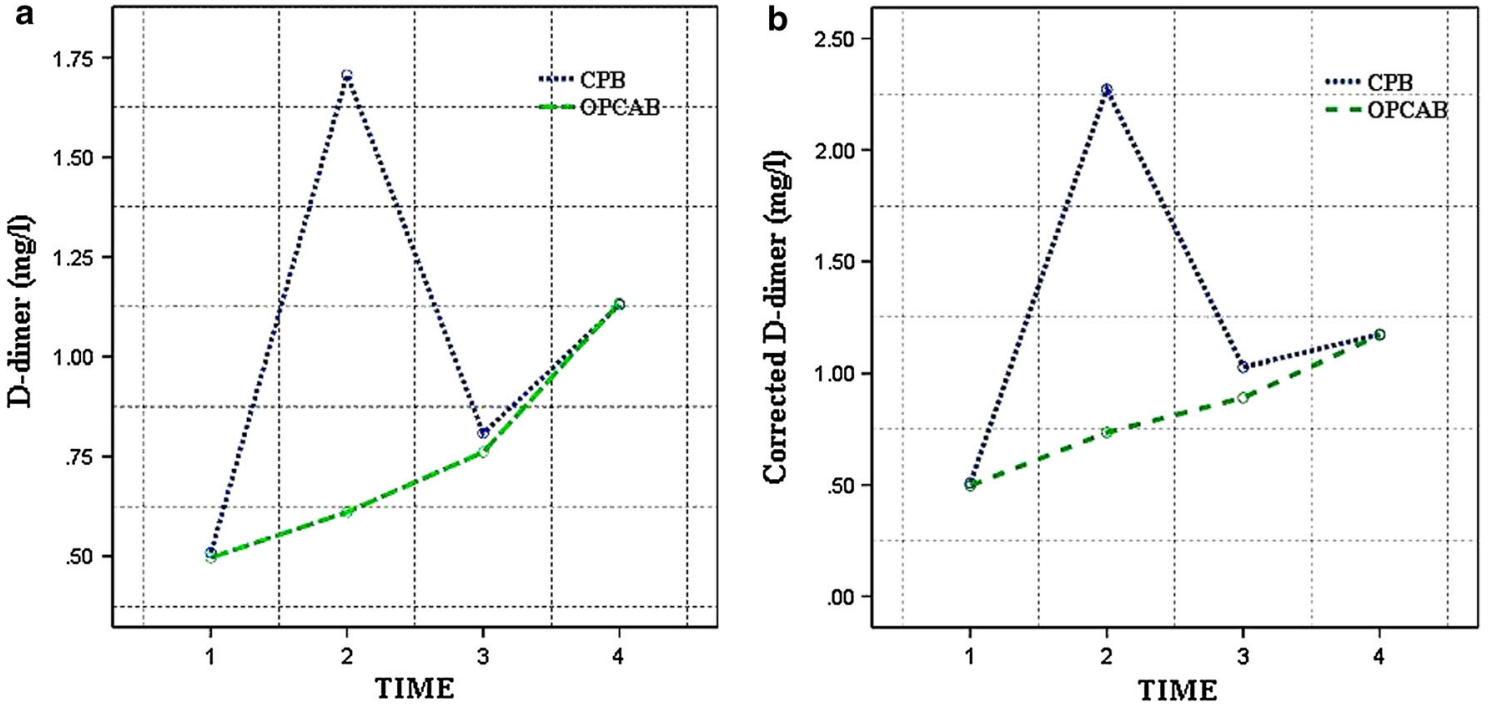

Fig. 4 a Concentration of D-dimer at four time points in two groups of patients without correction for hemodilution. Data points represent mean. b Concentration of D-dimer at four time points in two groups of patients with correction for hemodilution. Data points represent mean

CPB. Compared with the on-pump CABG group, prothrombin fragment 1.2 (F1.2) and D-dimer levels were significantly lower in patients having CABG surgery performed off-pump. In OPCAB patients, F1.2 and D-dimer levels increased more gradually and peaked on day 4 . In both groups, plasma concentrations of von Willebrand factor increased from the first postoperative day compared with baseline and peaked at 4th postoperative day.

Paulitsch et al. [27] observed that concentrations of PAI1 and D-dimer were greater early after surgery in patients undergoing on-pump surgery. And opined that the prothrombotic state might be a consequence of extracorporeal bypass, compensation in response to bleeding or both. Vedin et al. [28] similarly observed lower concentrations of fibrin D-dimer and prothrombin fragment $1+2$ during surgery in the off-pump group $(P<0.001)$. Paparella et al. [29] concluded that thrombin formation was more pronounced in patients having on-pump bypass grafting. Patients subjected to off-pump bypass grafting had normally functioning platelets and a weak activation of the fibrinolytic system. Parolari et al. [30] observed that activation of coagulation and of fibrinolytic pathways as well as of endothelium were relatively delayed in off-pump group compared to on-pump group. And suggested that the 
avoidance of extracorporeal circulation protects from the early appearance of a prothrombotic state. All these observations are comparable to that of our study.

In this prospective study of OPCAB versus on-pump $\mathrm{CABG}$, we found two temporally different patterns: the CPB group had a significantly more pronounced activation of coagulation and fibrinolysis in the immediate postoperative period, whereas the OPCAB group demonstrated a delayed postoperative response that became almost equal in magnitude to that of the CPB group in the later postoperative period.

\section{Conclusions}

On-pump surgery was associated with excessive fibrinolytic activity immediately after operation. The off-pump group demonstrated relatively less activation of coagulation and fibrinolysis and delayed postoperative response in comparison to on-pump group.

Conflict of interest The authors declare that they have no conflict of interest.

\section{References}

1. van Dijk D, Nierich AP, Jansen EW, Nathoe HM, Suyker WJ, Diephuis JC, van Boven WJ, Borst C, Buskens E, Grobbee DE, Robles De Medina EO, de Jaegere PP, Octopus Study Group (2001) Early outcome after off-pump versus on-pump coronary bypass surgery: results from a randomized study. Circulation 104:1761-1766

2. Angelini GD, Taylor FC, Reeves BC, Ascione R (2002) Early and midterm outcome after off-pump and on-pump surgery in Beating Heart Against Cardioplegic Arrest Studies (BHACAS 1 and 2): a pooled analysis of two randomised controlled trials. Lancet 359:1194-1199

3. Edmunds LH Jr (1998) Inflammatory response to cardiopulmonary bypass. Ann Thorac Surg 66(5 Suppl):S12-S16

4. Parolari A, Colli S, Mussoni L, Eligini S, Naliato M, Wang X, Gandini S, Tremoli E, Biglioli P, Alamanni F (2003) Coagulation and fibrinolytic markers in a two-month follow-up of coronary bypass surgery. J Thorac Cardiovasc Surg 125:336-343

5. Mannucci L, Gerometta PS, Mussoni L, Antona C, Parolari A, Salvi L, Biglioli P, Tremoli E (1995) One month follow-up of haemostatic variables in patients undergoing aortocoronary bypass surgery: effect of aprotinin. Thromb Haemost 73:356-361

6. Moor E, Hamsten A, Blomback M, Herzfeld I, Wiman B, Ryden L (1994) Hemostatic factors and inhibitors and coronary artery bypass grafting: preoperative alterations and relation to graft occlusion. Thromb Haemost 72:335-342

7. Li N, Astudillo R, Ivert T, Hjemdahl P (2003) Biphasic prothrombotic and inflammatory responses after coronary artery bypass surgery. J Thromb Haemost 1:470-476

8. Parolari A, Alamanni F, Cannata A, Naliato M, Bonati L, Rubini $P$ et al (2003) OPCAB versus CABG: meta-analysis of currently available randomized trials. Ann Thorac Surg 76:37-40

9. Sabik JF, Gillinov AM, Blackstone EH, Vacha C, Houghtaling PL, Navia J, Smedira NG, McCarthy PM, Cosgrove DM, Lytle
BW (2002) Does off-pump coronary surgery reduce morbidity and mortality? J Thorac Cardiovasc Surg 124:698-707

10. Biglioli P, Cannata A, Alamanni F, Naliato M, Porqueddu M, Zanobini M, Tremoli E, Parolari A (2003) Biological effects of off-pump versus on-pump coronary artery surgery: focus on inflammation, hemostasis and oxidative stress. Eur J Cardiothorac Surg 24:260-269

11. Eagle KA, Guyton RA, Davidoff R, Ewy GA, Fonger J, Gardner TJ, Gott JP, Herrmann HC, Marlow RA, Nugent W, O'Connor GT, Orszulak TA, Rieselbach RE, Winters WL, Yusuf S, Gibbons RJ, Alpert JS, Garson A Jr, Gregoratos G, Russell RO, Ryan TJ, Smith SC Jr (1999) ACC/AHA guidelines for coronary artery bypass graft surgery: executive summary and recommendations: a report of the American College of Cardiology/American Heart Association Task Force on Practice Guidelines (Committee to revise the 1991 guidelines for coronary artery bypass graft surgery). Circulation 100:1464-1480

12. Woodman RC, Harker LA (1990) Bleeding complications associated with cardiopulmonary bypass. Blood 76:1680-1697

13. Calafiore AM, Teodori G, Di Giammarco G, Vitolla G, Maddestra N, Paloscia L, Zimarino M, Mazzei V (1999) Multiple arterial conduits without cardiopulmonary bypass: early angiographic results. Ann Thorac Surg 67:450-456

14. Poirier NC, Carrier M, Lespérance J, Coté G, Pellerin M, Perrault LP, Pellettier LC (1999) Quantitative angiographic assessment of coronary anastomoses performed without cardiopulmonary bypass. J Thorac Cardiovasc Surg 117:292-297

15. Cartier R (1999) Systematic off-pump coronary artery revascularization: experience of 275 cases. Ann Thorac Surg 68:14941497

16. Koutlas TC, Elbeery JR, Williams JM, Moran JF, Francalancia NA, Chitwood WR Jr (2000) Myocardial revascularization in the elderly using beating heart coronary artery bypass surgery. Ann Thorac Surg 69:1042-1047

17. Calafiore AM, Di Giammarco G, Teodori G, Bosco G, D'Annunzio E, Barsotti A, Maddestra N, Paloscia L, Vitolla G, Sciarra A, Fino C, Contini M (1996) Left anterior descending coronary artery grafting via left anterior small thoracotomy without cardiopulmonary bypass. Ann Thorac Surg 61:1658-1663

18. Iacò AL, Contini M, Teodori G, Di Mauro M, Di Giammarco G, Vitolla G, Iovino T, Calafiore AM (1999) Off or on bypass: what is the safety threshold? Ann Thorac Surg 68:1486-1489

19. Casati V, Gerli C, Franco A, Della Valle P, Benussi S, Alfieri O, Torri G, D'Angelo A (2001) Activation of coagulation and fibrinolysis during coronary surgery: on-pump versus off-pump techniques. Anesthesiology 95:1103-1109

20. Englberger L, Immer FF, Eckstein FS, Berdat PA, Haeberli A, Carrel TP (2004) Off-pump coronary artery bypass operation does not increase procoagulant and fibrinolytic activity: preliminary results. Ann Thorac Surg 77:1560-1566

21. Ovrum E, Brosstad F, Am Holen E, Tangen G, Abdelnoor M, Oystese R (1996) Complete heparin-coated (CBAS) cardiopulmonary bypass and reduced systemic heparin dose; effects on coagulation and fibrinolysis. Eur J Cardiothorac Surg 10:449-455

22. Kojima T, Gando S, Kemmotsu O, Mashio H, Goda Y, Kawahigashi H, Watanabe N (2001) Another point of view on the mechanism of thrombin generation during cardiopulmonary bypass: role of tissue factor pathway inhibitor. J Cardiothorac Vasc Anesth 15:60-64

23. Boisclair MD, Lane DA, Philippou H, Sheikh S, Hunt B (1993) Thrombin production, inactivation and expression during open heart surgery measured by assays for activation fragments including a new ELISA for prothrombin fragment $\mathrm{F} 1+2$. Thromb Haemost 70:253-258

24. Møller CH, Steinbrüchel DA (2003) Platelet function after coronary artery bypass grafting: is there a procoagulant activity after 
off-pump compared with on-pump surgery? Scand Cardiovasc J 37:149-153

25. Sjoland H, Tengborn L, Stensdotter L, Herlitz J (2007) Lack of very strong association between pre-treatment fibrinogen and PAI-1 with long-term mortality after coronary bypass surgery. Cardiology 108:82-89

26. Lo B, Fijnheer R, Castigliego D, Borst C, Kalkman CJ, Nierich AP (2004) Activation of hemostasis after coronary artery bypass grafting with or without cardiopulmonary bypass. Anesth Analg 99:634-640

27. Paulitsch FS, Schneider D, Sobel BE, Rached R, Ramires J, Jatene F, Stolf N, Hueb W, Lopes NH (2009) Hemostatic changes and clinical sequelae after on-pump compared with off-pump coronary artery bypass surgery: a prospective randomized study. Coron Artery Dis 20:100-105
28. Vedin J, Antovic A, Ericsson A, Vaage J (2005) Hemostasis in off-pump compared to on-pump coronary artery bypass grafting: a prospective, randomized study. Ann Thorac Surg 80:586-593

29. Paparella D, Galeone A, Venneri MT, Coviello M, Scrascia G, Marraudino N, Quaranta M, de Luca Tupputi Schinosa L, Brister SJ (2006) Activation of the coagulation system during coronary artery bypass grafting: comparison between on-pump and offpump techniques. J Thorac Cardiovasc Surg 131:290-297

30. Parolari A, Mussoni L, Frigerio M, Naliato M, Alamanni F, Galanti A, Fiore G, Veglia F, Tremoli E, Biglioli P, Camera M (2005) Increased prothrombotic state lasting as long as 1 month after on-pump and off-pump coronary surgery. J Thorac Cardiovasc Surg 130:303-308 